\author{
RAFAŁ KOWALCZYK \\ ORCID: 0000-0002-2981-9226 \\ Uniwersytet Wrocławski
}

\title{
SANKCJE FINANSOWE W STRUKTURZE DOCHODÓW GMIN
}

\begin{abstract}
Abstrakt: Jednym z dochodów własnych jednostek samorządu terytorialnego są sankcje finansowe. Analiza uprawnień organów jednostek samorządu terytorialnego w zakresie wymiaru i poboru tych dochodów prowadzi do wniosku, że są one dużo mniejsze niż w przypadku innych dochodów własnych. Nazwy tych sankcji są w praktyce bardzo różne i rozproszone w różnych aktach prawnych. Dotyczy to zarówno przepisów dotyczących konstrukcji tych dochodów, jak i przepisów regulujących procedurę postępowania. Tym ważniejsze wydaje się ujednolicenie stosowania regulacji prawnych w zakresie tych dochodów.
\end{abstract}

Słowa kluczowe: sankcja, finanse, dochody własne, gmina, instrument prawny

\section{WPROWADZENIE}

Ustawa o dochodach jednostek samorządu terytorialnego ${ }^{1}$, regulując strukturę dochodów jednostek samorządu terytorialnego w kategorii dochodów własnych, wymienia wśród innych grup dochodów ze źródeł publicznych dochody z tytułu kar pieniężnych i grzywien. Choć ustawodawca powiela ten rodzaj dochodu wśród katalogu dochodów wszystkich szczebli samorządu terytorialnego, to $\mathrm{w}$ praktyce kary pieniężne wystąpią przede wszystkim jako źródło zasilenia budżetu gminy. Występowanie tego rodzaju dochodu budżetu samorządowego jako niedoprecyzowanej kategorii finansowo-prawnej implikuje pytania o miejsce kar pieniężnych (sankcji finansowych) w systemie dochodów budżetowych, jak również o instrumenty prawne przysługujące organom tych jednostek w zakresie kształtowania dochodów z tego źródła.

Rozważania poświęcone zasadniczemu tematowi należy poprzedzić przeglądem i ustaleniem zakresu pojęciowego normatywnych rozwiązań i pojęć używanych przez ustawodawcę. W przywołanej na wstępie ustawie posługuje się on bowiem zbiorczym pojęciem kar pieniężnych oraz grzywien, nie odróżniając ich od

${ }^{1}$ Ustawa z dnia 13 listopada 2003 roku, tekst jedn. Dz.U. z 2021 r. poz. 38 ze zm. 
siebie, a tym bardziej — nie definiując. Również w ustawie o finansach publicznych $^{2}$ pojawiają się tego rodzaju wpływy, występując w katalogu dochodów budżetu państwa opisanym w przepisie art. 111 pkt 12 ustawy, z tym że ustawodawca klasyfikuje je jako grzywny, mandaty i inne kary pieniężne. Ponadto znajdziemy je w przepisie art. 60 pkt $6 \mathrm{a}$, w katalogu niepodatkowych należności o charakterze publicznym, choć w tym miejscu ustawa przywołuje jedynie grzywny i mandaty. Regulacją istotną dla dalszych rozważań jest przepis art. 67 ust. 2 ustawy o finansach publicznych, w którym ustawodawca nakazał stosowanie przepisów postępowania administracyjnego do spraw z zakresu administracyjnych kar pieniężnych. Z tego krótkiego przeglądu przepisów można wywnioskować, że ustawodawca nie tylko wymienia różne rodzaje dochodów, w których charakterze można doszukiwać się funkcji sankcyjnej, ale też wskazuje na kilka istotnych cech dochodów z omawianej grupy. Po pierwsze klasyfikuje je jako dochody o charakterze publicznoprawnym, po drugie - umieszcza je w innej grupie niż dochody podatkowe czy z grupy danin publicznych, po trzecie nie dokonuje ani wyjaśnienia, czym się od siebie różnią, ani nie wskazuje choćby cech istotnych tej grupy dochodów, odwołując się do regulacji wynikających z innych szczególnych przepisów.

Pomimo braku definicji ustawowej w przepisach ustaw z zakresu gospodarki publicznymi zasobami finansowymi, oba rodzaje dochodów (kary i grzywny) należy zaliczyć do kategorii sankcji finansowych, czyli kategorii zbliżonej w swych cechach, a jednak odmiennej od danin publicznych. Rozpatrując sankcje finansowe przez pryzmat ich funkcji (tu należy dopatrywać się zasadniczej różnicy między nimi a daninami publicznymi), należy zwrócić uwagę że nie realizują one celu fiskalnego; służyć mają raczej penalizacji niepożądanych zachowań, dostarczając środków publicznych tylko przy okazji ${ }^{3}$. Sankcje finansowe pełnią przede wszystkim funkcję represyjną i prewencyjną, czasami restytucyjną, w najmniejszym zaś zakresie - fiskalną ${ }^{4}$. Na gruncie prawa finansów samorządowych sankcje finansowe należy traktować jako ten rodzaj dochodu publicznego, w którym kompetencje organów gminy w zakresie kształtowania ich wysokości czy innych elementów konstrukcyjnych zostały wyłączone lub znacznie ograniczone. To ustawodawca przejął na siebie prawo (a właściwie nie przekazał go żadnej innej instytucji ) wskazywania tych dóbr, których naruszenie powoduje reakcję podmiotu publicznego, regulując przy okazji wszystkie elementy konstrukcji prawnej tego dochodu publicznego, a organom wykonawczym pozostawiając kompetencje niezbędne jedynie do indywidualnych rozstrzygnięć w wymiarze lub płatności kar finansowych.

${ }^{2}$ Ustawa z dnia 27 sierpnia 2009 roku, tekst jedn. Dz.U. z 2021 r. poz. 305 ze zm.

3 Zob. A. Gorgol, Kontrowersje uregulowania prawnofinansowych środków ochrony środowiska. Zagadnienia finansowe, [w:] Prawne instrumenty ochrony środowiska, red. B. Jeżyńska, E. Kruk, Lublin 2016, s. 31.

4 Zob. J. Jendrośka, Karne zabezpieczenie wykonania dyrektyw administracji państwowej, [w:] System prawa administracyjnego, t. 3, red. T. Rabska, J. Łętowski, Wrocław 1978, s. 196. 


\section{PROCEDURA WYMIARU I POBORU SANKCJI FINANSOWYCH}

Przed analizą wybranych materialnoprawnych aktów prawnych regulujących omawianą kategorię dochodów należy odnieść się do regulacji prawnych wynikających z przepisów postępowania administracyjnego, zostały one bowiem dodane w 2017 roku do przepisów kodeksu postępowania administracyjnego ${ }^{5}$ (dział IVa) jako reguły postępowania w zakresie administracyjnych kar pieniężnych. Regulację tę należy traktować jako próbę systemowego uporządkowania zasad wymiaru i poboru dochodów budżetowych, które klasyfikowane są jako administracyjne kary pieniężne. Należy jednak podkreślić i wskazać jako niedopatrzenie ustawodawcy, że administracyjne kary pieniężne są jedynie częścią (rodzajem) sankcji finansowych, których zakres przedmiotowy jest znacznie szerszy i nie ogranicza się do kar administracyjnych (choć w praktyce trudno je wyraźnie rozgraniczyć). W doktrynie prawa administracyjnego dominuje przekonanie, że nie można w sposób identyczny traktować wszystkich sankcji finansowych wywodzących się z kręgu prawa administracyjnego jako administracyjnych kar pieniężnych, przede wszystkim ze względu na brak uwzględniania w ich charakterze elementu winy. Tak więc wobec użycia przez ustawodawcę różnych sformułowań i przesłanek wymiaru, inny charakter prawny będzie miała kara, a inny na przykład opłata podwyższona, choć bez wątpienia obie należy zaliczyć do sankcji administracyjnych o charakterze finansowym ${ }^{6}$.

Dokonanie zmian i wprowadzenie do przepisów k.p.a. nowego działu poświęconego karom administracyjnym należy traktować jako przynajmniej częściową próbę uporządkowania rozproszonej i niejednolitej regulacji prawnej, która dotyczy sankcji administracyjnych przybierających wymiar pieniężny. Pomimo niewątpliwych korzyści wynikających z usystematyzowania przepisów proceduralnych, ustawodawca powołał do istnienia wiele sfer nie podlegających tym przepisom. Trzeba zauważyć, że zgodnie z brzmieniem przepisu art. 189a $§ 2$ ustawy (k.p.a.) należy traktować regulacje tego działu jako nieobowiązujące w odniesieniu do regulacji wynikających z przepisów ustaw szczególnych, jeśli te ostatnie w inny sposób regulują zasady wymiaru, poboru i stosowania ulg w zakresie kar administracyjnych. $Z$ drugiej jednak strony omawiane przepisy k.p.a. należy traktować jako mające walor szczególny wobec przepisów regulujących postępowanie w zakresie niepodatkowych należności budżetowych. Tak więc przepisy ustawy o finansach publicznych nie będą stosowane w zakresie, w jakim przepisy k.p.a. regulować będą zagadnienia dotyczące wymiaru, poboru i stosowania ulg w należnościach budżetowych zaliczanych do kategorii kar administracyjnych. Z kolei $\mathrm{w}$ zakresie wynikającym $\mathrm{z}$ analizowanego działu przepisy k.p.a. nie będą mia-

5 Ustawa z dnia 14 czerwca 1960 roku, tekst jedn. Dz.U. z 2020 r. poz. 256 ze zm.

${ }^{6}$ Zob. J. Zimmermann, Aksjomaty prawa administracyjnego, Warszawa 2013, s. 239; L. Staniszewska, Administracyjne kary pieniężne. Studium z zakresu prawa administracyjnego, materialnego i procesowego, Poznań 2017, s. 26. 
ły zastosowania, jeśli przepisy szczególne regulować będą ten sam przedmiotowy zakres nakładania, egzekwowania kar czy też stosowania ulg w ich zakresie.

Przykładem nie do końca przemyślanej (bo niejednolitej i nie pełnej) regulacji ustawowej są przepisy ustawy o utrzymaniu czystości i porządku w gminach. W ustawie tej stosowanie przepisów k.p.a. będzie wyłączone, a zastosowanie mieć będą przepisy ordynacji podatkowej: w całości do opłat, częściowo zaś w stosunku do kar przewidzianych w rozdziale 4d ustawy o utrzymaniu czystości i porządku w gminach ${ }^{7}$. Zgodnie z przepisem (9zf ustawy) do kar pieniężnych stosuje się jedynie przepisy działu III ustawy z dnia 29 sierpnia 1997 roku — Ordynacja podatkowa (dalej: o.p.), z tym że uprawnienia organów podatkowych przysługują wójtowi, burmistrzowi, prezydentowi miasta oraz wojewódzkiemu inspektorowi ochrony środowiska. W obu jednak przypadkach (zarówno opłat, jak i kar) stosownie do art. 189a $\S 2$ pkt 1 i 2 k.p.a. w wypadku uregulowania w przepisach odrębnych przesłanek wymiaru administracyjnej kary pieniężnej oraz odstąpienia od nałożenia administracyjnej kary pieniężnej lub udzielenia pouczenia nie stosuje się w tym zakresie przepisów działu $\mathrm{IVa}^{8}$. Przechodząc do ocen rozwiązań w zakresie proceduralnych zasad wymierzania i poboru kar administracyjnych o charakterze finansowym, należy z jednej strony pochwalić ustawodawcę za próbę ujednolicenia dotychczasowej regulacji. Z drugiej jednak - stwierdzić (choć uwzględniając okoliczności usprawiedliwiające ustawodawcę działającego w realiach różnych i rozproszonych regulacji prawnych), że można było zasady proceduralne omawianych dochodów publicznych jeszcze bardziej doprecyzować, a przede wszystkim zdecydować się na jedną procedurę (ze wskazaniem na ordynację podatkową jako lepiej przystosowaną do realizacji dochodów publicznych) w zakresie wymierzania i poboru sankcji finansowych.

Warto w tym miejscu odnieść się również do pojęć używanych przez ustawodawcę w omawianych przepisach k.p.a., mających wymiar definicyjny i materialnoprawny. Przez administracyjną karę pieniężną rozumie się określoną w ustawie sankcję o charakterze pieniężnym nakładaną przez organ administracji publicznej $\mathrm{w}$ drodze decyzji, w następstwie naruszenia prawa polegającego na niedopełnieniu obowiązku albo naruszeniu zakazu ciążącego na osobie fizycznej, osobie prawnej albo jednostce organizacyjnej nieposiadającej osobowości prawnej (art. 189b k.p.a.). Wśród istotnych elementów administracyjnej kary pieniężnej należy wskazać ustawową podstawę prawną nakładania tej kary (co wyklucza inne źródła podstaw nakładania kar administracyjnych). Brak jest możliwości ustalania administracyjnych kar pieniężnych jedynie na podstawie aktu prawa miejscowego czy innego aktu podustawowego, co oczywiście nie wyklucza doprecyzowywania

7 Ustawa z dnia 13 września 1996 roku, tekst jedn. Dz.U. z 2020 r. poz. 1439 ze zm.

8 Z uzasadnienia do Wyroku Wojewódzkiego Sądu Administracyjnego w Szczecinie z dnia 6 września 2018 roku, sygn. akt II SA/Sz 425/18, SIP LEX. 
w tej drodze aktu ustawowego. Do administracyjnych kar pieniężnych nie można również zaliczyć kar umownych wynikających ze stosunków cywilnoprawnych.

Drugą istotną cechą kary administracyjnej jest wskazanie w ustawowej podstawie prawnej sankcji prawnej określonego zachowania lub zaniechania, co więcej musi to być sankcja o charakterze pieniężnym. Ustawodawca nie zawsze jest konsekwentny w nazewnictwie świadczeń, które należy kwalifikować jako administracyjne kary pieniężne, używając sformułowań kara pieniężna czy opłata podwyższona9 ${ }^{9}$. Jest to niewątpliwie praktyka naganna nie tylko ze względu na technikę prawodawczą, ale również szereg kardynalnych zasad dotyczących ustroju państwa. Jeśli bowiem przyjąć, że ustawodawca dąży do stworzenia kategorii prawnej w postaci kary administracyjnej, to powinien używać we wszystkich aktach prawnych, w których przewiduje nakładanie kary administracyjnej, takiej właśnie nazwy na jej określenie. Jeśli zaś zakres sankcji finansowych w regulacjach prawnych ma być szerszy niż tylko administracyjne kary pieniężne, to ustawodawca powinien ujednolicić nazewnictwo i wyznaczyć granice rozróżniania administracyjnych kar pieniężnych od innych finansowych sankcji występujących w języku prawnym ${ }^{10}$.

Pojęcie sankcji użyte w analizowanym przepisie k.p.a. należy rozumieć jako reakcję na spełnienie dyspozycji normy prawnej zakazującej lub nakazującej wskazane ustawowo zachowanie. Jako część normy prawnej sankcja zapowiada użycie lub zapowiedź użycia przymusu lub innej dolegliwości. Ze względu na rodzaj przymusu należy sankcje dzielić na sankcje przymusu, egzekucji oraz nieważności ${ }^{11}$. Sankcje, o których mowa w przepisie art. 189b k.p.a., należy zakwalifikować do grupy sankcji represyjnych, charakteryzujących się pozbawieniem podmiotu naruszającego dyspozycję przepisu cennych dla niego dóbr ${ }^{12}$. Jeśli więc przepisy prawa zawierają zagrożenie na wypadek spełnienia się jakiegoś niepożądanego stanu faktycznego lub prawnego związanego z zachowaniem się lub zaniechaniem ze strony adresata normy prawnej, a represyjność zyskuje wymiar wyrażony w pieniądzu, to spełniony zostaje warunek określony w komentowanej definicji prawnej.

Na koniec należy wskazać na wymóg orzekania o karze administracyjnej przez organ administracji publicznej. Najkrócej komentując ten wymóg, należy stwierdzić, że tylko organ posiadający ten status, wynikający z przepisów ustrojowych, jest kompetentny do wymierzania administracyjnych kar pieniężnych, a co więcej, wymiar tej kary musi zostać oszacowany w drodze decyzji administracyjnej. Oczywiste jest więc, że wymiaru administracyjnej kary pieniężnej dokonać może jedynie organ władny do wydawania decyzji, a nie innych rozstrzygnięć

9 Zob. A. Wróbel, Komentarz do art. 189b, [w:] A. Wróbel, M. Jaśkowska, Kodeks postępowania administracyjnego. Komentarz, Warszawa 2018, s. 1199.

10 Zob. L. Staniszewska, Administracyjne kary pieniężne, str. 27.

11 S. Kaźmierczyk, Sankcja normy prawnej, [w:] Wprowadzenie do nauk prawnych. Leksykon tematyczny, red. A. Bator, Warszawa 2012, s. 159.

12 T. Chauvin, T. Stawecki, P. Winczorek, Wstęp do prawoznawstwa, Warszawa 2018, s. 115. 
administracyjnych, co w wypadku rozważanej tematyki bezpośrednio wskazuje na organ wykonawczy gminy.

Przepisy k.p.a. narzucają organom uwzględnienie przesłanek wymiaru kary wymienionych w art. 189d, jak również działania siły wyższej (art. 189e) oraz wskazują przesłanki odstąpienia od nałożenia kary pieniężnej (art.189f). Należy przyjąć imperatywny charakter tych przepisów, obligujący organ do uwzględnienia okoliczności wskazanych przez ustawę i oparcie się na nich przy miarkowaniu kary dla osoby zobowiązanej. Są one więc normatywnymi przesłankami mającymi wpływ na ustalenie wysokości administracyjnych kar pieniężnych ${ }^{13}$. Należy jednak odczytywać ten przepis również przez pryzmat poczynionych wcześniej uwag dotyczących innych ustaw regulujących sankcje administracyjne: dyrektywy wymiaru kar administracyjnych przewidziane w k.p.a. nie znajdują zastosowania w przypadku kar nakładanych decyzjami związanymi, czyli takimi w stosunku do których ustawodawca nakazuje stosować pewien jednoznaczny mechanizm sankcji pieniężnej ${ }^{14}$.

\section{INSTRUMENTY KSZTAŁTOWANIA DOCHODÓW Z SANKCJI FINANSOWYCH WYNIKAJĄCE Z K.P.A.}

Przepisy przywołanego wcześniej rozdziału ustawy (k.p.a.) zawierają dwa rozwiązania istotne dla kompetencji organu wykonawczego gminy w zakresie wymiaru i poboru administracyjnych kar pieniężnych — przedawnienie ukarania oraz zasady udzielania ulg. Już wstępna analiza tych regulacji ukazuje podobieństwo do zasad przyjętych zarówno w przepisach ordynacji podatkowej, jak i w ustawie o finansach publicznych. Zagadnienia terminu przedawnienia, skutków niezapłacenia kary w terminie, jak i przesłanek przerwania biegu przedawnienia, są spójne z rozwiązaniami wcześniej wymienionych ustaw, co wskazuje na próbę systemowego rozwiązania tych instytucji. Warto w tym miejscu nawiązać również do jednej z niewielu sytuacji, w których organ administracji (wójt, burmistrz, prezydent) może skorzystać z instrumentu władztwa dochodowego. Chodzi o zasady przyznawania ulg w zakresie wykonania kar administracyjnych. Sam zakres instrumentów przysługujących organowi administracyjnemu w art. 189k jest identyczny jak w przywołanych aktach prawnych (o.p. i ustawie o finansach publicznych), gdyż uprawnia go do odroczenia terminu wykonania administracyjnej kary pieniężnej lub rozłożenia jej na raty, odroczenia terminu wykonania zaległej administracyjnej kary pieniężnej lub rozłożenia jej na raty, umorzenia ad-

13 R. Stankiewicz, Komentarz do art. 189d k.p.a, [w:] Kodeks postępowania Administracyjnego. Komentarz, red. R. Hauser, M. Wierzbowski, Warszawa 2018, s. 1311.

14 Zob. Wyrok Wojewódzkiego Sądu Administracyjnego w Warszawie z dnia 11 lipca 2018 roku, sygn. akt VIII SA/Wa 205/18, SIP LEX. 
ministracyjnej kary pieniężnej w całości lub części, umorzenia odsetek za zwłokę w całości lub części ${ }^{15}$.

Jednakże stosowanie tych instrumentów w zakresie administracyjnych kar pieniężnych może być dokonywane jedynie $\mathrm{w}$ ramach postępowania inicjowanego na wniosek osoby zobowiązanej do poniesienia kary. Przesłanki udzielenia ulg zostały oparte o rowiązania znane z innych aktów prawnych wykorzystujących instrument uznania administracyjnego - ważny interes podatnika lub ważny interes publiczny, przy czym konieczne jest uwzględnienie dodatkowych przesłanek w przypadku prowadzenia działalności gospodarczej przez osobę zobowiązaną. Z istoty wykorzystanej konstrukcji wynika, że ani organ nadzoru, ani sąd administracyjny nie mogą zobowiązać organu administracyjnego do wydania decyzji o umorzeniu bądź odmowie umorzenia administracyjnej kary pieniężnej w całości lub części (w przypadku stwierdzenia co najmniej jednej z przesłanek). Nie może też oceniać kryteriów przyjętych przez organ, a uzasadniających wybór opcji decyzyjnej. Jednakże kontrola działania organu (instancyjna i sądowa) dotyczyć może przypadków korzystania przez organy z przyznanej im kompetencji w sposób woluntarystyczny, zupełnie nieracjonalny lub sprzeczny z podstawowymi zasadami konstytucyjnymi ${ }^{16}$. Jako regulację wyjątkową w stosunku do ogólnie obowiązujących należy wskazać okoliczność, gdy to na stronie spoczywa obowiązek wykazania przesłanek ku zastosowaniu ulg $\mathrm{w}$ zakresie realizacji kar administracyjnych, co do pewnego stopnia zwalnia organ orzekający z dokonania wszelkich czynności niezbędnych do dokładnego wyjaśnienia stanu faktycznego sprawy ${ }^{17}$.

\section{INSTRUMENTY KSZTAŁTOWANIA DOCHODÓW Z SANKCJI FINANSOWYCH WYNIKAJĄCE Z PRZEPISÓW SZCZEGÓLNYCH}

Po raz kolejny należy wskazać na prymat przepisów szczególnych w relacji do zagadnień regulowanych omawianym wcześniej zakresem przepisów postępowania administracyjnego. Sytuacja taka ma miejsce w przywołanych już wcześniej przepisach ustawy o utrzymaniu czystości i porządku w gminie. Przepisy tej ustawy nazywają sankcje finansowe wprost karami pieniężnymi, jednakże w zakresie ich wymiaru nakazują stosować przepisy o.p., choć w zakresie ograniczonym do Działu III tej ustawy. Regulacja ustawy o czystości i porządku w gminach zawiera szereg przepisów szczególnych konstytuujących odpowiedzialność i postępowanie w sprawach kar pieniężnych w inny sposób niż przepisy o.p., która może być

15 Zob. B. Adamiak, Komentarz do art. 189k, [w:] B. Adamiak, J. Borkowski, Kodeks postępowania administracyjnego. Komentarz, Warszawa 2017, s. 985.

16 Zob. wyrok WSA w Warszawie z dnia 5 lutego 2020 roku, sygn. akt V SA/WA 292/19, LEX nr 3078800.

17 Zob. wyrok WSA w Białymstoku z dnia 14 lutego 2019 roku, sygn. akt II SA/Bk 698/18, LEX nr 2633572. 
stosowana jedynie w zakresie nieuregulowanym ustawą o czystości i porządku w gminach. W odniesieniu do kar wynikających z przywołanego aktu prawnego brak jest jakichkolwiek kompetencji organu stanowiącego gminy do ich wprowadzania, kształtowania zasad ich wymierzania czy poboru. Niewielki zakres decyzyjny pozostawiono również organowi wykonawczemu gminy. Ten zakres swobody dotyczy przede wszystkim wymiaru wysokości kary w granicach zakresu ustawowego oraz zastosowania ulg w jej płatności. Co warte podkreślenia, odpowiedzialność za naruszenie przepisów ustawy należy traktować jako obligatoryjną, co oznacza konieczność wszczęcia postępowania w sprawach naruszeń określonych przez ustawę. Pewna swoboda oceny subiektywnych okoliczności sprawy i - w wyniku tego — oparcie wysokości kary na istnieniu ustalonych przez ustawodawcę przesłanek została ograniczona do kilku deliktów wskazanych w przepisach art. 9x ust. 1 pkt 2-4, art. 9xa pkt 2, art. 9xaa pkt 1, art. 9xb pkt 1. Kryteriami, które organ wymierzający karę musi wziąć pod uwagę, są: stopień szkodliwości czynu, zakres naruszenia oraz dotychczasowa działalność podmio$\mathrm{tu}^{18}$. Poza wskazanymi wyżej przypadkami organ wymierzający karę nie posiada instrumentów jej miarkowania, wymierzając ją w wysokości wynikającej z przepisów ustawy. Poza wskazanymi wyżej zasadami wymiaru kar organ wykonawczy stosować może wszystkie te instrumenty władztwa, które przewiduje o.p. w dziale poświęconym zobowiązaniom podatkowym, a więc również te, które dotyczą stosowania ulg w wymiarze i poborze zobowiązań podatkowych.

Kolejnym aktem prawnym, który zawiera podobne do wcześniej omawianych regulacje dotyczące sankcji finansowych (w zakresie tych stanowiących dochód budżetu gminy), jest ustawa o ochronie przyrody ${ }^{19}$. Przepisy art. 88 i 89 ustawy wskazują przesłanki i reguły wymierzania sankcji finansowej nazywanej w tym miejscu przez ustawodawcę ,administracyjną karą pieniężną”. Ich podstawowym celem jest zapewnienie prowadzenia działalności człowieka w zgodzie z zasadą zrównoważonego rozwoju oraz obciążenie kosztami strat w środowisku naturalnym podmiotu, który był ich sprawcą ${ }^{20}$. Administracyjna kara pieniężna za usunięcie drzewa bez wymaganego zezwolenia nie ma charakteru odszkodowawczego. Jest to odpowiedzialność za delikt administracyjny, przy której wartość przyrodnicza usuwanego drzewa nie ma znaczenia, ponieważ jest to odpowiedzialność za działanie bez zezwolenia ${ }^{21}$. Przy okazji tej części rozważań w pełni

$18 \mathrm{Na}$ temat definicyjnych elementów przestępstwa i wykroczenia w deliktach administracyjnych zob. W. Radecki, Materialna treść czynów zabronionych pod groźba kary pieniężnej (na przykładach z dziedziny ochrony środowiska), [w:] Państwo prawa i prawo karne. Księga jubileuszowa Profesora Andrzeja Zolla, t. 2, red. P. Kardas, T. Sroka, W. Wróbel, Warszawa 2012, s. 471.

19 Ustawa z dnia 16 kwietnia 2004 roku, tekst jedn. Dz.U. z 2020 r. poz. 55 ze zm.

20 Zob. K. Gruszecki, Kary pieniężne za usuwanie, uszkadzanie albo niszczenie drzew lub krzewów, Wrocław 2018, s. 18.

21 Zob. Wyrok Wojewódzkiego Sądu Administracyjnego w Poznaniu z dnia 2 kwietnia 2014 roku, sygn. akt II SA/Po 806/13, SIP LEX. 
aktualne pozostają uwagi dotyczące wyłączenia przepisów kodeksu postępowania administracyjnego w zakresie, w jakim przepisy u.o.p. odmiennie regulują zagadnienia wymiaru i poboru kary pieniężnej.

Tak jak w poprzednio omawianej regulacji wyłączne uprawnienia kształtowania kar przewidzianych przez przepisy ustawy o ochronie przyrody stanowią kompetencję organu wykonawczego gminy. I tak jak w poprzedniej sytuacji, organ ten jest związany dyrektywami ustawowymi, co do obligatoryjności kary i jej wysokości. Wymiar kary jest obowiązkiem organu i nie podlega uznaniu administracyjnemu. Przepisy w sposób imperatywny nakazują organowi wykonawczemu gminy wymiar administracyjnej kary pieniężnej przy stwierdzeniu popełnienia deliktów administracyjnych wymienionych w art. 88 ust. 1 ustawy:

W przypadku zaistnienia okoliczności wyczerpujących hipotezę art. 88 ust. 1 pkt 2 u.o.p., a więc usunięcia drzew bez wymaganego zezwolenia, organ ma bezwzględny obowiązek wymierzenia $\mathrm{z}$ tego tytułu administracyjnej kary pieniężnej. Jego zastosowanie wymaga jednak przede wszystkim uprzedniego ustalenia tego, kto i kiedy dokonał usunięcia drzew. Aby wydać decyzję merytoryczną w przedmiocie wymierzenia kary pieniężnej, konieczne jest bowiem ustalenie, po pierwsze, że miało miejsce usunięcie drzewa, a po wtóre, że istnieje podmiot, na który kara administracyjna może i powinna zostać nałożona ${ }^{22}$.

Elementy związane z wysokością kary, terminem płatności i przedawnieniem prawa do wymiaru ustawodawca uregulował wyczerpująco, pozostawiając organowi wykonawczemu gminy zakres związany z umorzeniem 50\% wymierzonej kary osobom fizycznym, które na cele niezwiązane z prowadzeniem działalności gospodarczej usunęły lub zniszczyły drzewo lub krzew albo uszkodziły drzewo, w przypadku gdy osoby te nie są w stanie uiścić kary w pełnej wysokości bez znacznego uszczerbku utrzymania koniecznego dla siebie i rodziny, jeżeli dochód miesięczny na jednego członka gospodarstwa domowego nie przekracza $50 \% \mathrm{mi}$ nimalnego wynagrodzenia za pracę $\mathrm{w}$ danym roku.

Uwagę zwracają użyte przez ustawodawcę przesłanki, które organ wymierzający karę musi brać pod uwagę przy rozpatrywaniu wniosku osoby zobowiązanej do uiszczenia kary. Należy więc, po pierwsze, przyjąć, że postępowanie w zakresie umorzenia kary jest odrębne od postępowania zmierzającego do wymiaru kary. Po drugie, treść przesłanek warunkujących zastosowanie umorzenia, a dotyczących sytuacji osobistej i majątkowej osoby zobowiązanej do poniesienia kary, wydają się wykluczać wszczęcie tego postępowania z urzędu ${ }^{23}$. Należy też zwrócić uwagę na inny niż w podobnych regulacjach (na przykład w o.p. czy ustawie o finansach publicznych) warunek zastosowania instytucji umorzenia. Zasadniczymi przesłankami zastosowania ulg w świadczeniach publicznych

22 Wyrok Wojewódzkiego Sądu Administracyjnego w Opolu z dnia 22 lipca 2014 roku, sygn. akt II SA/Op 307/14, SIP LEX.

23 Podobnie uważa K. Gruszecki, Komentarz do ustawy o ochronie przyrody, Warszawa 2016, s. 451. 
są przemawiające za dokonaniem umorzenia ważny interes zobowiązanego lub interes publiczny. $\mathrm{W}$ omawianym przepisie ustawodawca położył nacisk jedynie na sytuację materialną osoby zobowiązanej, czego nie można utożsamiać z jej ważnym interesem, który może przybierać inny wymiar niż tylko finansowy. Tymczasem ustawodawca $\mathrm{w}$ przepisach u.o.p. uzależnił możliwość dokonania umorzenia (do wskazanej ustawowo wysokości) od przesłanek subiektywnych i obiektywnych. Subiektywną przesłanką jest sytuacja prywatna osoby zobowiązanej (nie będącej przedsiębiorcą), która wobec obowiązku zapłaty kary może ulec diametralnej zmianie na niekorzyść osoby zobowiązanej, jak i rodziny tej osoby. Druga przesłanka dotyczy obiektywnych danych dotyczących wysokości dochodów osiąganych przez osobę zobowiązaną, które nie mogą przekroczyć wartości ustalonych statystycznie. Należy przyjąć, że warunkiem zastosowania ulgi jest kumulatywne wystąpienie obu przesłanek. Jednocześnie konsekwencją wykorzystania uznania administracyjnego w omawianym przepisie musi być przyjęcie prawa do umorzenia kary pieniężnej, a nie obowiązku ciążącego na organie wymierzającym karę, nawet w przypadku wystąpienia przesłanek umorzeniowych.

Nie można traktować możliwości odroczenia terminu zapłaty kary w okolicznościach przewidzianych w art. 88 ust. 4 ustawy jako uprawnienia organu wykonawczego gminy. Zgodnie z tym przepisem, organ wymierzający karę za zniszczenie drzewa lub krzewu odracza termin jej płatności na okres pięciu lat, jeżeli stopień zniszczenia drzewa lub krzewu nie wyklucza zachowania jego żywotności. Przesłanki zastosowania tego instrumentu wymagają od organu wymierzającego karę przeprowadzenia postępowania dowodowego i to $\mathrm{w}$ oparciu o wiedzę specjalistyczną, by stwierdzić czy drzewa lub krzewy mogą zachować żywotność. W przypadku gdy drzewo rokuje zachowanie żywotności, organ administracji ma obowiązek odroczenia terminu płatności kary pieniężnej na okres pięciu lat. Ustalenia w tym zakresie powinny być dokonane już w postępowaniu w sprawie wymierzenia kary pieniężnej. Odroczenie terminu płatności ma bowiem miejsce $\mathrm{w}$ decyzji wymierzającej karę pieniężną, $\mathrm{z}$ tym że powyższe rozwiązanie nie będzie miała zastosowania do kar wymierzanych za inne delikty przewidziane w art. 88 ustawy. Należy zgodzić się z twierdzeniem, że skoro w u.o.p. przewidziana została możliwość odstąpienia od wymierzania kary lub umorzenia wymierzonej kary, to nie będą miały zastosowania przepisy k.p.a. regulujące tą kwestię — w tym art. 189f — w myśl zasady lex specialis derogat legi generali $^{24}$. Tak więc w pozostałym zakresie przedmiotowym, innym niż wskazany w przepisie art. 88 ust. 1 pkt 3, zastosowanie będą mieć przepisy kodeksu postępowania administracyjnego.

Ostatnim instrumentem kształtowania kar pieniężnych (choć mówienie o prawie kształtowania kary jest $\mathrm{w}$ tym przypadku sporym nadużyciem) jest odstąpienie

${ }^{24}$ Zob. Wyrok Wojewódzkiego Sądu Administracyjnego w Warszawie z dnia 26 maja 2020 roku, sygn. akt II OSK 3007/19, LEX nr 3058884. 
od wymiaru kary za usunięcie drzewa, krzewu lub ich uszkodzenia w okolicznościach uzasadnionych stanem wyższej konieczności. Odstąpienie od wymiaru kary jest obligatoryjne dla organu wymierzającego karę, jeśli wystąpi przesłanka określona w przepisie art. 89 ust. 7 ustawy. Wobec braku odpowiedniej regulacji należy przyjąć, że okoliczności uzasadnione stanem wyższej konieczności mogą być podniesione przez osobę, która dopuściła się deliktu, i powinny być brane pod uwagę z urzędu przez organ właściwy do wymierzenia kar. Z działaniem siły wyższej, a co za tym idzie - wystąpieniem stanu wyższej konieczności, będziemy mieli do czynienia wówczas, gdy będzie ona spowodowana działaniem czynników obiektywnych, których w normalnym stanie nie da się przewidzieć, a wartość chronionego dobra musi być wyższa od tego, które ma ulec zniszczeniu ${ }^{25}$.

Ostatnim przykładem regulacji odrębnej od tych wynikających z k.p.a., a dotyczących wymiaru i poboru administracyjnych kar pieniężnych, jest ustawa o drogach publicznych ${ }^{26}$. Zgodnie z przepisem art. 29a u.d.p. zarządca drogi wymierza karę pieniężną za wybudowanie zjazdu z drogi bez zezwolenia. $Z$ treści przepisu art. 29a ust. 1 u.d.p. wynika kategoryczne zobowiązanie organu do wymierzenia kary, co oznacza, że decyzja nie zależy od uznania organu, jeżeli ustalono, że doszło do wybudowania lub przebudowania zjazdu. W takim przypadku organ jest zobligowany do nałożenia na stronę kary pieniężnej stosownie do art. 40 ust. 4 u.d.p. i odpowiedniego przepisu prawa miejscowego. W przypadku stwierdzenia takiej sytuacji, organ nie może nawet badać przyczyn wybudowania lub przebudowy zjazdu bez zezwolenia zarządcy drogi, oceniać stopnia winy strony ani też miarkować wysokości wymierzanej kary. Może jedynie, po stwierdzeniu faktu wybudowania lub przebudowy zjazdu bez zezwolenia, wydać decyzję administracyjną wymierzającą karę w przewidzianej wysokości ${ }^{27}$. W podobny sposób, na podstawie art. 40 ust. 12 ustawy, wymierzana jest kara pieniężna za zajęcie pasa drogowego bez odpowiedniego zezwolenia. Ustawodawca nakazuje zarządcy drogi wymierzenie, na drodze decyzji administracyjnej, kary pieniężnej równej dziesięciokrotności opłaty za zajęcie pasa drogowego. Nie ma przepisu prawa, który uwalniałby od odpowiedzialności administracyjnej za zajęcie pasa drogowego lub pozwalał na miarkowanie kary z uwagi na upływ czasu między stwierdzeniem istnienia obiektu posadowionego w pasie drogowym bez zezwolenia, a datą wszczęcia postępowania w przedmiocie nałożenia kary pieniężnej za zajęcie pasa drogowego bez zezwolenia zarządcy drogi. Tak jak w przypadku kary za bezprawne wybudowanie lub przebudowę zjazdu w przypadku zajęcia pasa drogowego odpowiedzialność administracyjna za jego bezprawne zajęcie jest zobiektywizowana, niezależna od winy sprawcy. Nieistotna jest przyczyna braku zezwolenia na zajęcie pasa drogowego ani też okoliczności zdarzenia. Dla

25 K. Gruszecki, Ustawa o ochronie przyrody. Komentarz, str. 615 n.

26 Ustawa z dnia 21 marca 1985 roku, tekst jedn. Dz.U. z 2020 r. poz. 470 ze zm.

27 Zob. Wyrok Wojewódzkiego Sądu Administracyjnego w Warszawie z dnia 9 maja 2017 roku, sygn. akt VII SA/Wa 1377/16, SIP LEX. 
wymierzenia sankcji istotne jest wyłącznie to, że podmiot takiego zezwolenia nie posiadał i czy był świadomy tego, że go nie posiada. Ustawową przesłanką nałożenia kary pieniężnej jest faktyczne zajęcie pasa drogowego bez zezwolenia ${ }^{28}$. Inaczej jednak niż w przypadku pozostałych kar pieniężnych, organ stanowiący gminy ma wpływ na wysokość tych wymierzanych na podstawie ustawy o drogach publicznych, gdyż ich wysokość jest pochodną wysokości opłat za zajęcie pasa drogowego ustalanych $\mathrm{w}$ drodze aktu prawa miejscowego przez radę gminy na zasadach określonych w części poświęconej opłatom. Uchwalając więc wysokość opłat za zajęcie pasa drogowego, organ stanowiący gminy wpływa również na wysokość kar za zajęcie pasa drogowego bez zezwolenia.

\section{ZAKOŃCZENIE}

Pojęcie sankcji finansowych jest utrwalone w doktrynie prawa finansowego, jednakże w sferze normatywnej nie wydaje się już tak jednolite. Ustawodawca nie tylko używa różnych nazw sankcji finansowych, ale też stosuje różne procedury niezbędne do ich realizowania. Sankcje finansowe, choć nie są najważniejsze ze względów fiskalnych, stanowią istotny element dochodów własnych posiadających charakter publiczno-prawny. Tym donioślejsza wydaje się regulacja prawna wynikająca z przepisów postępowania administracyjnego, która tylko częściowo, ale jednak uporządkowała zasady wymiaru i poboru tego rodzaju dochodu publicznego. Wprowadzenie do przepisów postępowania administracyjnego zasad postępowania $\mathrm{z}$ administracyjnymi karami pieniężnymi niewątpliwie wpłynie na pewność i przejrzystość w zakresie wymiaru i poboru tego rodzaju dochodów, jednakże poza tą regulacją pozostaje ogromna liczba sankcji finansowych, o których była mowa wyżej. Niejednolitość nazw sankcji finansowych, połączona z różnymi procedurami stosowanymi przy ich wymiarze i poborze, nie przyczynia się do budowania spójnego wewnętrznie systemu prawnego. Również używanie na określenie tej grupy dochodów terminu „dochody własne” musi być dyskusyjne, a w każdym razie wymaga wyraźnego podkreślenia ograniczonych przez ustawodawcę instrumentów kształtowania tych dochodów przez samą jednostkę samorządu terytorialnego. Ograniczoność tych instrumentów w zestawieniu z takimi dochodami własnymi, jak dochody z tytułu danin publicznych, jest bardzo wyraźna i pozwala nazywać ten rodzaj dochodów określeniem „własne” w zasadzie jedynie przez pryzmat wpływów budżetowych.

28 Zob. wyrok Naczelnego Sądu Administracyjnego z dnia 25 września 2020 roku, sygn. akt II GSK 3900/17, LEX nr 3062905. 


\title{
FINANCIAL SANCTIONS IN THE STRUCTURE OF COMMUNITY INCOME
}

\author{
Summary
}

One of the own revenues of local government units are financial sanctions. The analysis of the powers of local self-government authorities with regard to the assessment and collection of these revenues leads to the conclusion that they are much smaller than any other own revenues. The names of these sanctions in practice vary significantly and are scattered in different legal acts. This applies both to the rules regarding construction of this revenue and to the regulations governing the procedure. Therefore, it would appear to be particularly important to unify the application of legal regulations concerning these incomes.

Keywords: sanction, finance, own revenue, commune, legal instrument

\section{BIBLIOGRAFIA}

Adamiak B., Borkowski J., Kodeks postepowania administracyjnego. Komentarz, Warszawa 2017. Chauvin T., Stawecki T., Winczorek P., Wstęp do prawoznawstwa, Warszawa 2018.

Gorgol A., Kontrowersje uregulowania prawnofinansowych środków ochrony środowiska. Zagadnienia finansowe, [w:] Prawne instrumenty ochrony środowiska, red. B. Jeżyńska, E. Kruk, Lublin 2016.

Gruszecki K., Komentarz do ustawy o ochronie przyrody, Warszawa 2016.

Jendrośka J., Karne zabezpieczenie wykonania dyrektyw administracji państwowej, [w:] System prawa administracyjnego, t. 3, red. T. Rabska, J. Łętowski, Wrocław 1978.

Kaźmierczyk S., Sankcja normy prawnej, [w:] Wprowadzenie do nauk prawnych. Leksykon tematyczny, red. A. Bator, Warszawa 2012.

Radecki W., Materialna treść czynów zabronionych pod groźba kary pieniężnej (na przykładach $z$ dziedziny ochrony środowiska), [w:] Państwo prawa i prawo karne. Księga jubileuszowa Profesora Andrzeja Zolla, t. 2, red. P. Kardas, T. Sroka, W. Wróbel, Warszawa 2012.

Staniszewska L., Administracyjne kary pieniężne. Studium z zakresu prawa administracyjnego materialnego i procesowego, Poznań 2017.

Stankiewicz R., Komentarz do art. 189d k.p.a., [w:] Kodeks postępowania administracyjnego. Komentarz, red. R. Hauser, M. Wierzbowski, Warszawa 2018.

Wróbel A., Jaśkowska M., Kodeks postępowania administracyjnego. Komentarz, Warszawa 2018.

Zimmermann J. Aksjomaty prawa administracyjnego, Warszawa 2013.

\section{WYKAZ AKTÓW PRAWNYCH}

Ustawa z dnia 14 czerwca 1960 roku — Kodeks postępowania administracyjnego, tekst jedn. Dz.U. z 2020 r. poz. 256 ze zm.

Ustawa z dnia 21 marca 1985 roku o drogach publicznych, tekst jedn. Dz.U. z 2020 r. poz. 470 ze zm. Ustawa z dnia 13 września 1996 roku o utrzymaniu czystości i porządku w gminach, tekst jedn. Dz.U. z 2020 r. poz. 1439 ze zm.

Ustawa z dnia 13 listopada 2003 roku o dochodach jednostek samorządu terytorialnego, tekst jedn. Dz.U. z 2021 r. poz. 38 ze zm.

Ustawa z dnia 16 kwietnia 2004 roku o ochronie przyrody, tekst jedn. Dz.U. z 2020 r. poz. 55 ze zm. Ustawa z dnia 27 sierpnia 2009 roku o finansach publicznych, tekst jedn. Dz.U. z 2021 r. poz. 305 ze zm. 


\section{WYKAZ ORZECZEŃ}

Wyrok Wojewódzkiego Sądu Administracyjnego w Poznaniu z dnia 2 kwietnia 2014 roku, sygn. akt II SA/Po 806/13.

Wyrok Wojewódzkiego Sądu Administracyjnego w Opolu z dnia 22 lipca 2014 roku, sygn. akt II SA/Op 307/14.

Wyrok Wojewódzkiego Sądu Administracyjnego w Warszawie z dnia 9 maja 2017 roku, sygn. akt VII SA/Wa 1377/16.

Wyrok Wojewódzkiego Sądu Administracyjnego w Warszawie z dnia 11 lipca 2018 roku, sygn. akt VIII SA/Wa 205/18.

Wyrok Wojewódzkiego Sądu Administracyjnego w Szczecinie z dnia 6 września 2018 roku, sygn. akt II SA/Sz 425/18.

Wyrok Wojewódzkiego Sądu Administracyjnego w Białymstoku z dnia 14 lutego 2019 roku, sygn. akt II SA/Bk 698/18.

Wyrok Wojewódzkiego Sądu Administracyjnego w Warszawie z dnia 5 lutego 2020 roku, sygn. akt V SA/WA 292/19.

Wyrok Wojewódzkiego Sądu Administracyjnego w Warszawie z dnia 26 maja 2020 roku, sygn. akt II OSK 3007/19.

Wyrok Naczelnego Sądu Administracyjnego z dnia 25 września 2020 roku, sygn. akt II GSK $3900 / 17$. 